\title{
Immediate Reactions to More Than 1 NSAID Must Not Be Considered Cross-Hypersensitivity Unless Tolerance to ASA Is Verified
}

\author{
Pérez-Alzate $\mathrm{D}^{1 *}$, Cornejo-García $\mathrm{JA}^{2,3 *}$, Pérez-Sánchez $\mathrm{N}^{2}$, Andreu I4, \\ García-Moral $\mathrm{A}^{5}$, Agúndez JA ${ }^{6}$, Bartra J5, Doña $\mathrm{I}^{2}$, Torres $\mathrm{MJ}^{2}$, Blanca $\mathrm{M}^{2}$, \\ Blanca-López $\mathrm{N}^{1}$, Canto $\mathrm{G}^{1}$
}

\author{
'Allergy Service, Infanta Leonor University Hospital, Madrid, Spain \\ ${ }^{2}$ Allergy Unit, Malaga Regional University Hospital-IBIMA, UMA, Malaga, Spain \\ ${ }^{3}$ Research Laboratory, Malaga Regional University Hospital-IBIMA, UMA, Malaga, Spain \\ ${ }^{4}$ Chemical Technology Institute, UPV-CSIC, Polytechnic University of Valencia, Valencia, Spain \\ ${ }^{5}$ Allergy Unit, Pneumology and Allergy Service, Clinic Hospital, Barcelona, Spain \\ ${ }^{6}$ Department of Pharmacology, University of Extremadura, Caceres, Spain \\ *Both authors contributed equally to this manuscript.
}

J Investig Allergol Clin Immunol 2017; Vol. 27(1): 32-39

doi: $10.18176 /$ jiaci.0080

\begin{abstract}
Background: Individuals who develop drug hypersensitivity reactions (DHRs) to chemically unrelated nonsteroidal anti-inflammatory drugs (NSAIDs) are considered cross-hypersensitive. The hallmark for this classification is that the patient presents a reaction after intake of or challenge with acetylsalicylic acid (ASA). Whether patients react to 2 or more NSAIDs while tolerating ASA remains to be studied (selective reactions, SRs).

Objective: To identify patients with SRs to 2 or more NSAIDs including strong COX-1 inhibitors.

Methods: Patients who attended the Allergy Service of Hospital Infanta Leonor, Madrid, Spain with DHRs to NSAIDs between January 2011 and December 2014 were evaluated. Those with 2 or more immediate reactions occurring in less than 1 hour after intake were included. After confirming tolerance to ASA, the selectivity of the response to 2 or more NSAIDs was demonstrated by in vivo and/or in vitro testing or by controlled administration.

Results: From a total of 203 patients with immediate DHRs to NSAIDs, $16(7.9 \%)$ met the inclusion criteria. The patients presented a total of 68 anaphylactic or cutaneous reactions (mean [SD], 4.2 [2.1]). Most reactions were to ibuprofen and other arylpropionic acid derivatives and to metamizole. Two different NSAIDs were involved in 11 patients and 3 in 5 patients.

Conclusions: Patients with NSAID-induced anaphylaxis or urticaria/angioedema should not be considered cross-hypersensitive unless tolerance to ASA is verified.

Key words: NSAID-hypersensitivity. Immediate reactions. Cross-hypersensitivity. Selective reactions.
\end{abstract}

\section{Resumen}

Introducción: Los individuos que desarrollan reacciones de hipersensibilidad a antiinflamatorios no esteroideos (AINE) no relacionados químicamente se consideran intolerantes cruzados. La característica esencial para ser incluidos en esta categoría es que presenten un resultado positivo tras la administración de AAS. La cuestión de si estos pacientes responden a dos o más AINE y toleran AAS no ha sido estudiada (reacciones selectivas a múltiples AINE, RS).

Objetivos: Identificar pacientes con RS a dos o más AINE, incluidos inhibidores potentes de COX-1.

Métodos: Se evaluaron los pacientes que acudieron al servicio de alergia del Hospital Infanta Leonor con una historia de hipersensibilidad a AINE desde enero de 2011 a diciembre de 2014. Únicamente se consideraron los casos con dos o más reacciones a AINE diferentes 
y que se produjeron durante la primera hora tras la ingesta del fármaco (reacciones inmediatas). Tras confirmar la tolerancia a AAS, se evaluó la selectividad de la reacción mediante pruebas in vivo/in vitro o administración controlada del medicamento.

Resultados: De un total de 203 pacientes con reacciones inmediatas a AINE 16 (7,9\%) se ajustaron a los criterios establecidos. Los pacientes presentaron 68 reacciones anafilácticas o urticaria/angioedema (media de 4,2 22,1 ). El ibuprofeno y otros derivados arilpropiónicos y el metamizol fueron los fármacos más frecuentemente implicados. En 11 pacientes las reacciones fueron inducidas por dos AINE diferentes, mientras que en otros 5 fueron tres los medicamentos implicados.

Conclusiones: Los pacientes con anafilaxia o urticaria/angioedema a diferentes AINE no deben ser incluidos dentro del grupo de intolerancia cruzada hasta verificar su tolerancia a AAS.

Palabras clave: Hipersensibilidad a AINE. Reacciones inmediatas. Hipersensibilidad cruzada. Reacciones selectivas.

\section{Introduction}

Nonsteroidal anti-inflammatory drugs (NSAIDs) are the most frequent triggers of drug hypersensitivity reactions (DHRs) [1]. In recent years, a number of studies have supported this finding [2-5]. In contrast to reactions to ß-lactams (BLs), which are immunologically mediated [6], DHRs to NSAIDs may be induced by both specific immunological mechanisms (allergic or selective reactions [SRs]) and mechanisms not based on immunological recognition (cross-hypersensitivity reactions [CRs]) [7]. Although the latter are responsible for the largest number of affected patients in some countries $[1,8]$, SRs account for a considerable proportion in others $[9,10]$. SRs have been reported to all NSAIDs, independently of their capacity for inhibiting the COX-1 enzyme [9,11], and in all age ranges, including children [12,13]. Patients who experience CRs to NSAIDs react to strong COX-1 inhibitors, including acetylsalicylic acid (ASA) [7]. In fact, ASA must be administered to discriminate between SRs and CRs $[7,14]$.

DHRs are giving considerable cause for concern $[15,16]$, with an increase in the number of drugs and mechanisms involved [1]. The 2 major culprit groups involved in DHRs in both children and adults are NSAIDs and BLs [1,2]. In fact, hypersensitivity to one group is considered a risk factor for developing reactions to the other $[17,18]$.

The first evidence of reactions to several drugs in a single individual was provided by Harris and Harris [19] and later by Sullivan [20]. The drugs involved in both cases were antibiotics. The patient's condition was originally deemed multidrug allergy syndrome. However, this denomination was based on general assumptions with no reference to the potential underlying mechanisms [21,22]. Coexistence of IgE antibodies in a specific immunological response, for example, in immediate reactions to BLs, has not been proven to date [23], except for anaphylactic reactions to amoxicillin-clavulanic acid, where clinical observations indicate that patients can experience an immediate reaction to both drugs [18]. With respect to T-cell responses to drugs, a number of studies have shown that nonimmediate reactions can occur with chemically unrelated drugs [24,25].

In the case of DHRs to NSAIDs, a major question is that of SRs to unrelated NSAIDs. There is some evidence indicating that individuals may react to several NSAIDs but tolerate ASA $[10,26]$. Contrary to $\mathrm{BL}$ reactions, where all drugs share a common ring that may influence the specificity of the response and cross-reactivity [6,18], NSAIDs comprise a heterogeneous family of chemical structures with a variable degree of cross-reactivity within each group [9,11]. In this manuscript, we present findings for a series of patients who developed immediate SRs to 2 or more NSAIDs, verify tolerance to ASA, and assess the involvement of the culprit drug(s) using challenge testing.

\section{Methods}

\section{Patient Selection}

The study population comprised patients who attended the Allergy Service of Infanta Leonor Hospital, Madrid, Spain from January 2011 to December 2014 after experiencing DHRs attributed to NSAIDs. Patients with challenge-confirmed DHRs to 2 or more chemically unrelated NSAIDs and tolerance to ASA were considered to have SRs to several NSAIDs and were therefore included in the study.

The study was performed according to the principles of the Declaration of Helsinki and approved by the local ethics committee. All participants were informed orally about the study and signed the corresponding informed consent document.

\section{Allergology Workup}

The general diagnostic algorithm is outlined in the Figure. Skin testing was performed with those drugs for which positive immediate results have already been reported, namely, metamizole [27], paracetamol [28], and diclofenac [29]. Concentrations were used as previously reported [29-31]. The basophil activation test (BAT) was performed exclusively for pyrazolone derivatives as described elsewhere [27].

The drug challenge was performed using previously described concentrations [8]. In patients who presented more than 2 episodes with the same drug, challenge testing with the culprit drug was not performed.

\section{Statistical Analysis}

The chi-square test was used to analyze differences in nominal variables between groups, and the Mann-Whitney test was used to compare quantitative variables. $P$ values were based on 2 -tailed tests, with values $<.05$ considered statistically significant. 


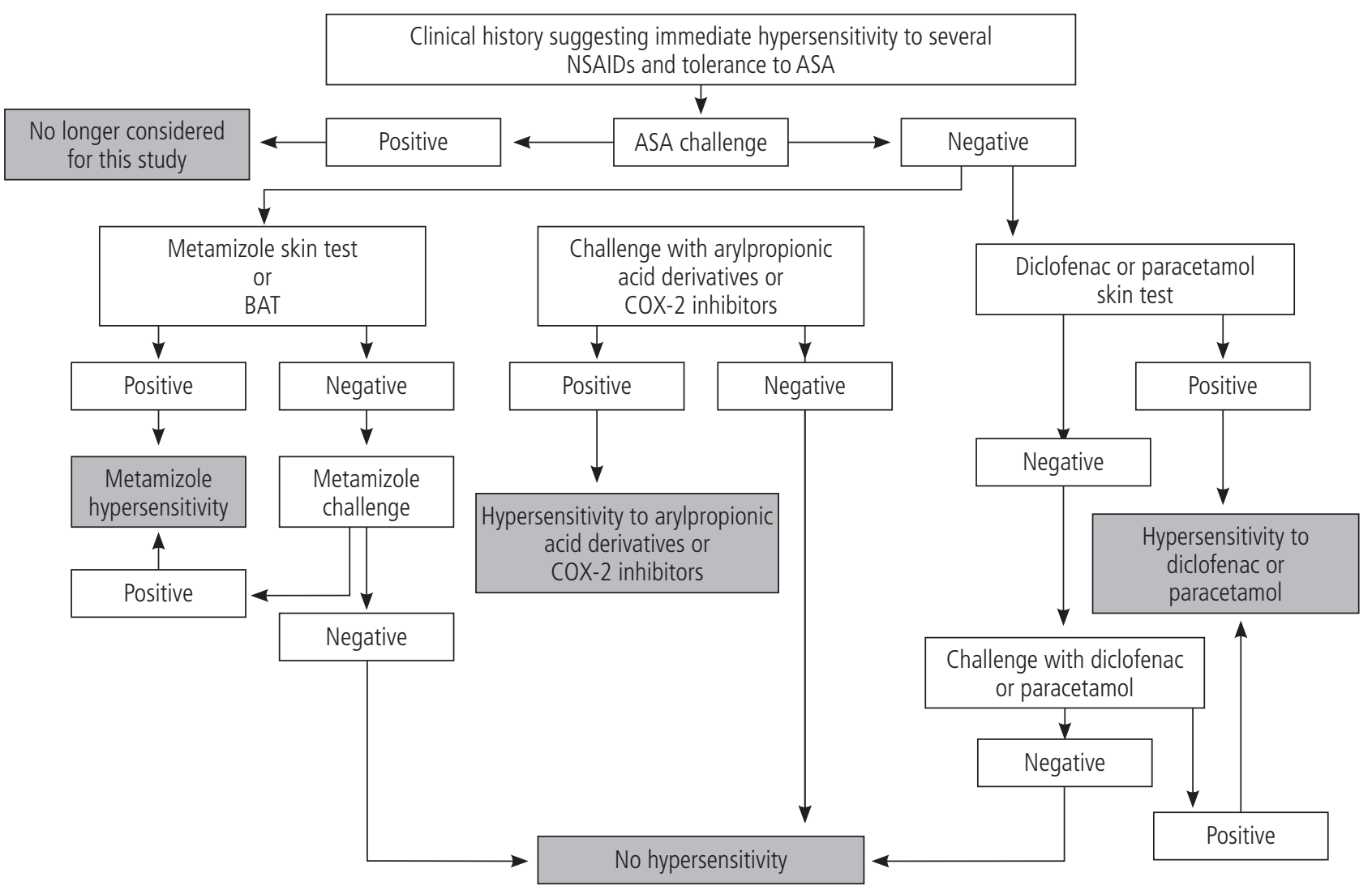

Figure. Algorithm for the allergology workup. NSAID indicates nonsteroidal anti-inflammatory drug; ASA, acetylsalicylic acid; BAT, basophil activation test; COX, cyclooxygenase.

\section{Results}

\section{Demographic and Clinical Characteristics}

From a total of 697 patients with confirmed diagnosis of hypersensitivity to NSAIDs, 203 presented SRs. Of these, 16 individuals met the inclusion criteria to be considered selective reactors to various NSAIDs. The patients included in this study did not report allergic reactions to BLs, other antibiotics, or other drugs.

Analysis of the demographic and clinical characteristics of patients revealed no statistically significant differences in age between females and males (47.2 [12.8] and 34.8 [12.1] years, respectively) (Table 1). Females were more commonly affected. A total of 68 episodes were registered in the clinical histories reported (mean of 4.2 [2.1]), with no sex differences. Two NSAIDs were the culprits in 11 patients whereas 3 NSAIDs were implicated in the remaining 5 patients. The drugs eliciting the episodes were metamizole (27 episodes, $39.7 \%$ ), ibuprofen (22 episodes, 32.4\%), paracetamol ( 6 episodes, $8.8 \%$ ), dexketoprofen ( 5 episodes, $7.4 \%$ ), naproxen ( 4 episodes, 5.9\%), diclofenac (3 episodes, $4.4 \%$ ), and celecoxib (1 episode, 1.4\%) (Table 1). Analysis by group of NSAIDs revealed that arylpropionic acid derivatives induced the highest number of episodes $(45.6 \%, \mathrm{p}<0.001)$. Metamizole induced a reaction in 15 of 16 patients, followed by ibuprofen in 8 of 16 cases $(P<.001)$. The arylpropionic acid derivative group in particular was implicated in $75 \%$ of cases $(P=.046)$. Interestingly, paracetamol also induced DHRs in 3 patients (responsible for a total of 6 episodes).

According to the clinical history, the time interval between drug intake and onset of symptoms was variable. For ibuprofen it was less than 30 minutes in 5 cases and between 30 and 60 minutes in 3 cases. In all patients who experienced several episodes to the same drug, the time interval was similar. The time interval for naproxen was less than 30 minutes in all cases; the time interval for metamizole was less than 30 minutes for 12 patients and 30-60 minutes for 3 patients. Evaluation by clinical entity revealed that anaphylactic shock occurred in 6 patients, anaphylaxis in 6, urticaria in 9, and urticaria/ angioedema in 3 . Isolated angioedema was only recorded in 1 patient (Table 1$)$.

Classification according to the number of episodes per patient showed that 1 patient had 10 episodes, 3 had 6, 2 had 5, 4 had 4,2 had 3, and 4 had 2 (Table 1), that is, $75 \%$ of patients had experienced 3 or more episodes. When repeated clinical entities occurred with the same drug, these tended to appear with the same time interval and presented with similar clinical characteristics. 
Table 1. Demographic and Clinical Data of the Patients

\begin{tabular}{|c|c|c|c|c|c|c|}
\hline Patient No. & Sex & Age, y & $\begin{array}{l}\text { Total No. } \\
\text { of Episodes }\end{array}$ & $\begin{array}{l}\text { Drugs Involved } \\
\text { (No. of Episodes) }\end{array}$ & $\begin{array}{c}\text { Time } \\
\text { Interval, min }\end{array}$ & Reaction \\
\hline 1 & $\mathrm{~F}$ & 51 & 2 & $\begin{array}{l}\text { Metamizole (1) } \\
\text { Naproxen (1) }\end{array}$ & $\begin{array}{l}<30 \\
<30\end{array}$ & $\begin{array}{l}\text { Anaphylactic shock } \\
\text { Anaphylactic shock }\end{array}$ \\
\hline 2 & $\mathrm{M}$ & 50 & 3 & $\begin{array}{l}\text { Metamizole (2) } \\
\text { Diclofenac (1) }\end{array}$ & $\begin{array}{l}<30 \\
<30\end{array}$ & $\begin{array}{l}\text { Anaphylactic shock } \\
\text { Urticaria/angioedema }\end{array}$ \\
\hline 3 & $\mathrm{~F}$ & 32 & 4 & $\begin{array}{l}\text { Ibuprofen (3) } \\
\text { Metamizole (1) }\end{array}$ & $\begin{array}{l}<30 \\
<30\end{array}$ & $\begin{array}{l}\text { Urticaria } \\
\text { Urticaria }\end{array}$ \\
\hline 4 & $\mathrm{~F}$ & 53 & 10 & $\begin{array}{l}\text { Ibuprofen (5) } \\
\text { Dexketoprofen (1) } \\
\text { Metamizole (4) }\end{array}$ & $\begin{array}{l}30-60 \\
30-60 \\
30-60\end{array}$ & $\begin{array}{l}\text { Urticaria } \\
\text { Urticaria } \\
\text { Urticaria }\end{array}$ \\
\hline 5 & $\mathrm{~F}$ & 45 & 2 & $\begin{array}{l}\text { Metamizole (1) } \\
\text { Naproxen (1) }\end{array}$ & $\begin{array}{l}<30 \\
<30\end{array}$ & $\begin{array}{l}\text { Anaphylactic shock } \\
\text { Anaphylaxis }\end{array}$ \\
\hline 6 & $\mathrm{M}$ & 28 & 6 & $\begin{array}{c}\text { Ibuprofen (4) } \\
\text { Metamizole (2) }\end{array}$ & $\begin{array}{l}<30 \\
<30\end{array}$ & $\begin{array}{l}\text { Angioedema } \\
\text { Angioedema }\end{array}$ \\
\hline 7 & $\mathrm{~F}$ & 43 & 4 & $\begin{array}{l}\text { Paracetamol (2) } \\
\text { Celecoxib (1) } \\
\text { Metamizole (1) }\end{array}$ & $\begin{array}{c}<30 \\
<30 \\
30-60\end{array}$ & $\begin{array}{c}\text { Urticaria/angioedema } \\
\text { Urticaria } \\
\text { Urticaria }\end{array}$ \\
\hline 8 & $\mathrm{M}$ & 38 & 5 & $\begin{array}{l}\text { Ibuprofen (1) } \\
\text { Metamizole (1) } \\
\text { Paracetamol (3) }\end{array}$ & $\begin{array}{l}<30 \\
<30 \\
<30\end{array}$ & $\begin{array}{l}\text { Anaphylaxis } \\
\text { Anaphylaxis } \\
\text { Urticaria }\end{array}$ \\
\hline 9 & $\mathrm{~F}$ & 72 & 4 & $\begin{array}{l}\text { Diclofenac (1) } \\
\text { Metamizole (3) }\end{array}$ & $\begin{array}{l}30-60 \\
30-60\end{array}$ & $\begin{array}{l}\text { Anaphylaxis } \\
\text { Anaphylaxis }\end{array}$ \\
\hline 10 & $\mathrm{~F}$ & 23 & 5 & $\begin{array}{l}\text { Ibuprofen (1) } \\
\text { Dexketoprofen (3) } \\
\text { Metamizole (1) }\end{array}$ & $\begin{array}{l}<30 \\
<30 \\
<30\end{array}$ & $\begin{array}{l}\text { Anaphylaxis } \\
\text { Urticaria } \\
\text { Anaphylaxis }\end{array}$ \\
\hline 11 & $\mathrm{M}$ & 18 & 4 & $\begin{array}{c}\text { Ibuprofen (2) } \\
\text { Metamizole (2) }\end{array}$ & $\begin{array}{c}30-60 \\
<30\end{array}$ & $\begin{array}{c}\text { Urticaria/angioedema } \\
\text { Urticaria }\end{array}$ \\
\hline 12 & $\mathrm{~F}$ & 42 & 6 & $\begin{array}{c}\text { Ibuprofen (4) } \\
\text { Metamizole (2) }\end{array}$ & $\begin{array}{l}<30 \\
<30\end{array}$ & $\begin{array}{l}\text { Urticaria } \\
\text { Urticaria }\end{array}$ \\
\hline 13 & $\mathrm{~F}$ & 54 & 2 & $\begin{array}{l}\text { Paracetamol (1) } \\
\text { Naproxen (1) }\end{array}$ & $\begin{array}{c}30-60 \\
<30\end{array}$ & $\begin{array}{c}\text { Urticaria } \\
\text { Anaphylactic shock }\end{array}$ \\
\hline 14 & $\mathrm{~F}$ & 55 & 2 & $\begin{array}{l}\text { Metamizole (1) } \\
\text { Naproxen (1) }\end{array}$ & $\begin{array}{l}<30 \\
<30\end{array}$ & $\begin{array}{l}\text { Anaphylactic shock } \\
\text { Anaphylaxis }\end{array}$ \\
\hline 15 & $\mathrm{M}$ & 40 & 3 & $\begin{array}{l}\text { Metamizole (2) } \\
\text { Diclofenac (1) }\end{array}$ & $\begin{array}{l}<30 \\
<30\end{array}$ & $\begin{array}{l}\text { Anaphylactic shock } \\
\text { Urticaria/angioedema }\end{array}$ \\
\hline 16 & $\mathrm{~F}$ & 50 & 6 & $\begin{array}{l}\text { Ibuprofen (2) } \\
\text { Dexketoprofen (1) } \\
\text { Metamizole (3) }\end{array}$ & $\begin{array}{c}30-60 \\
30-60 \\
<30\end{array}$ & $\begin{array}{l}\text { Urticaria } \\
\text { Urticaria } \\
\text { Anaphylaxis }\end{array}$ \\
\hline
\end{tabular}

\section{Allergology Workup}

In the case of metamizole, 7 out of 15 patients had a positive skin test result ( 2 by skin prick tests and 5 by intradermal tests) (Table 2). BAT was performed in the 8 cases with negative skin test results and yielded a positive result in 4 patients. Therefore, 11 cases were diagnosed by in vivo/in vitro testing. Three patients were diagnosed based on positive challenge results (Table 2). In patient No. 9, for whom the results of both skin testing and BAT were negative, a challenge was not performed, since the patient had previously experienced 3 repeated episodes of anaphylaxis and had cardiovascular risk factors. According to the clinical history, all positive intradermal skin test results (patients No. 2, 4, 7, 12, and 15), became negative 5 years after the last evaluation, and positive skin prick test results became negative while the intradermal test results remained positive. In patients with a negative skin test but positive BAT result (patients No. 1, 3, 10, and 16), the intradermal test results also became negative after 2 years (Table 2).

The results of the allergology workup with the other NSAIDs are presented in Table 3. In the case of arylpropionic acid derivatives, for which skin tests and BAT have not been validated, these procedures were not carried out. Challenge 
Table 2. Results of the Allergology Workup With Metamizole

\begin{tabular}{lcccl}
\hline Patient No. & Last Episode, mo & Skin Test & BAT & Drug Provocation Test \\
\hline 1 & 8 & Negative & Positive & ND \\
2 & 12 & Positive (IDT) & ND & ND \\
3 & 14 & Negative & Positive & ND \\
4 & 12 & Positive (IDT) & ND & ND \\
5 & 4 & Positive (prick) & ND & ND \\
6 & 12 & Negative & Negative & Facial and lip angioedema \\
7 & 8 & & (cumulative dose of 200 mg) \\
8 & 10 & Positive (IDT) & ND & ND \\
9 & 8 & Negative & Negative & Systemic pruritus, chest and abdominal \\
10 & 12 & ND & Negative & ND \\
11 & 18 & Negative & Positive & ND \\
12 & 16 & Negative & Negative & Facial erythema and generalized pruritus \\
14 & 2 & Positive (IDT) & ND & (cumulative dose of 115 mg) \\
15 & 12 & Positive (prick) & ND & ND \\
16 & 6 & Positive (IDT) & ND & ND \\
& & ND & Positive & ND
\end{tabular}

Abbreviations: BAT, basophil activation test; DPT, drug provocation test; IDT, intradermal test; ND, not done.

Table 3. Drug Provocation Test With Culprit Drugs Other Than Metamizole

\begin{tabular}{|c|c|c|c|c|c|}
\hline $\begin{array}{l}\text { Patient } \\
\text { No. }\end{array}$ & Drug & $\begin{array}{l}\text { DPT Time } \\
\text { Interval, } \text { min }^{\mathrm{a}}\end{array}$ & $\begin{array}{l}\text { Last } \\
\text { Dose, } \mathrm{mg}\end{array}$ & $\begin{array}{l}\text { Cumulative } \\
\text { Dose, mg }\end{array}$ & Clinical Symptoms During DPT \\
\hline 1 & Naproxen & 5 & 50 & 55 & Palmoplantar pruritus and wheals on the arms and legs \\
\hline 2 & Diclofenac & 20 & 20 & 50 & Generalized pruritus and lip angioedema \\
\hline 3 & ND & & & & \\
\hline 4 & ND & & & & \\
\hline 5 & Naproxen & 10 & 50 & 55 & Generalized pruritus and throat tightness \\
\hline 6 & ND & & & & \\
\hline 7 & $\begin{array}{l}\text { Paracetamol } \\
\text { Celecoxib }\end{array}$ & $\begin{array}{l}15 \\
20\end{array}$ & $\begin{array}{c}200 \\
60\end{array}$ & $\begin{array}{l}500 \\
120\end{array}$ & $\begin{array}{l}\text { Generalized pruritus with wheals on the face and chest } \\
\text { Generalized pruritus and wheals on the face }\end{array}$ \\
\hline 8 & Ibuprofen & 20 & 100 & 155 & Palmoplantar pruritus and wheals on the abdomen and chest \\
\hline 9 & Diclofenac & 40 & 15 & 30 & Cutaneous pruritus and wheals on the thorax, abdomen, and legs \\
\hline 10 & ND & & & & \\
\hline 11 & Ibuprofen & 50 & 200 & 500 & Pruritus and wheals on the thorax \\
\hline 12 & ND & & & & \\
\hline 13 & $\begin{array}{l}\text { Naproxen } \\
\text { Paracetamol }\end{array}$ & $\begin{array}{l}15 \\
30\end{array}$ & $\begin{array}{l}100 \\
200\end{array}$ & $\begin{array}{l}155 \\
500\end{array}$ & $\begin{array}{l}\text { Generalized pruritus and wheals, throat tightness and dyspnea } \\
\text { Pruritus and wheals on the abdomen }\end{array}$ \\
\hline 14 & Naproxen & 20 & 50 & 55 & Palmoplantar followed by generalized pruritus and wheals \\
\hline 15 & Diclofenac & 20 & 15 & 30 & Palmoplantar pruritus, urticaria, and lip angioedema \\
\hline 16 & Dexketoprofen & 15 & 20 & 50 & Generalized pruritus and wheals on the thorax, arms, and legs \\
\hline
\end{tabular}

Abbreviations: DPT, drug provocation test; ND, not done.

aTime elapsed between controlled administration of the drug and the appearance of symptoms. 
was performed in patients who reported only 1 or 2 episodes with the same drug or drug group (patients No. 1, 5, 8, 11, 13,14 , and 16). In cases involving naproxen, the cumulative dose was $55 \mathrm{mg}$ in 3 cases and $155 \mathrm{mg}$ in 1 case. One patient responded to a cumulative dose of $155 \mathrm{mg}$ of ibuprofen and another to $500 \mathrm{mg}$. Finally, patient No. 16 reacted to a cumulative dose of $50 \mathrm{mg}$ of dexketoprofen. All patients who reacted to arylpropionic acid derivatives did so at quantities below therapeutic doses, with the exception of patient No. 11.

Diagnosis was also made by challenge testing with the remaining drugs (Table 3 ). In cases involving diclofenac and/ or paracetamol, skin test results were negative at the maximum concentration recommended. With diclofenac, the cumulative dose eliciting a positive result was $30 \mathrm{mg}$ for patients No. 9 and 15, whereas patient No. 2 developed a reaction after a cumulative dose of $50 \mathrm{mg}$. In the case of paracetamol, the 2 challenge tests yielded positive results after cumulative doses of $500 \mathrm{mg}$. Finally, a positive result to the celecoxib challenge was obtained with a cumulative dose of $120 \mathrm{mg}$.

\section{Discussion}

We studied immediate SRs to various NSAIDs occurring less than 1 hour after intake. According to recent guidelines, these reactions fall within the category of single NSAID induced urticaria/angioedema or anaphylaxis, for which all patients must tolerate ASA [7,30]. From a total of 203 patients with immediate SRs to NSAIDs, we identified 16 who reacted to 2 or 3 chemically unrelated NSAIDs and were tolerant to ASA. In contrast to hypersensitivity to BLs [21,31], patients with DHRs to NSAIDs often experience repeated episodes as a result of incomplete knowledge about how to address the reactions $[8,32]$. Although multiple allergy to drugs was first reported more than 20 years ago [19,20], studies to elucidate the mechanism have been carried out only for T cell-dependent reactions, where sensitization to multiple drugs could occur both simultaneously and sequentially [19-21]. An imbalance of the immune system caused by effector and/or regulatory $\mathrm{T}$ cells may be involved [24,33].

In the case of immediate SRs to NSAIDs, some patients react to 2 different NSAIDs whilst tolerating ASA [10]. In this manuscript, we report on a series of patients who, after reporting repeated episodes of immediate reactions to 2 or more NSAIDs, were able to tolerate ASA.

Current data on arylpropionic acid derivatives indicate that these drugs are increasingly involved in immediate SRs, which are now almost as frequent as SRs to pyrazolone derivatives $[1,2,8]$. Although these drugs generate immunogenic adducts and induce T-cell responses [34], the potential adducts involved in selective immediate allergic reactions and the presence of specific IgE antibodies have not yet been addressed [9].

Another drug of interest was metamizole, a frequent elicitor of SRs $[9,35]$ in countries where it is still widely prescribed $[1,8,10]$. In our study, positive skin test or BAT results became negative over time, as usually occurs in IgEmediated responses to drugs [27]. The analysis of patients who developed a response to metamizole showed that $43.75 \%$ had positive results in skin tests, which is similar to the percentage reported in the present study (Table 2).
Analysis of the other drugs for which skin tests were performed (diclofenac and paracetamol) did not reveal a positive response, although some studies have shown that this can occur [28]. Therefore, drug involvement was established by drug provocation testing as reported elsewhere [8], in patients with only 1 reported episode or negative skin test result. We found that most patients responded at low drug concentrations. This finding is consistent with previous data showing that selective responders reacted at lower concentrations than cross-hypersensitive individuals [8].

In all the cases studied, reactions appeared less than 1 hour after intake. In cases similar to those described here, the presence of IgE antibodies has only been found for pyrazolones and ASA [36,37]. Although clinical evidence suggests an IgE mechanism for diclofenac, with positive skin test results in some cases, the presence of specific IgE antibodies has not been demonstrated [29]. In our study, all patients who reacted to diclofenac had negative skin test results, as reported elsewhere [38,39].

An intriguing question is why these patients developed an IgE-mediated response to several chemically unrelated NSAIDs but not to other drugs such as BLs, which are traditionally involved in IgE-mediated reactions. All the patients included in this study reported tolerance to BLs and other antibiotics.

The prevalence of immediate SRs is also worthy of comment. Published guidelines indicate that patients who react to various NSAIDs also react to ASA [7,14]. However, our results show that patients responding to various NSAIDs should be tested for tolerance to ASA. If consistent histories are provided, especially of repeated episodes to various NSAIDs, and tolerance to ASA is proven, the diagnosis of an SR to various NSAIDs must be considered. Although $7.9 \%$ of patients in the present series developed immediate SRs to 2 or more NSAIDs, the exact figure remains to be determined. Contributing factors include the number of NSAIDs and the time elapsed before patient evaluation. The larger the number of NSAIDs taken and the longer the time patients are exposed, the higher the probability of developing a new reaction. However, the influence of genetic background must also be considered.

In summary, we showed that immediate SRs to 2 or more NSAIDs can occur and that this phenotype must be taken into account in ASA-tolerant patients who report immediate reactions to various analgesics and NSAIDs. Further studies are in progress to determine the prevalence of such reactions.

\section{Funding}

JA Cornejo-García received funding from the Miguel Servet Program (Ref CP14/00034, Carlos III National Health Institute, Spanish Ministry of Economy and Competitiveness). The present study was supported by grants from the Carlos III National Health Institute RD12/0013 (RIRAAF Network), FIS PI12/02247, and FIS PI13/02598. It was also supported by the Andalusian Public Health Service (PI-0279-2012 and PI-0463-2013).

This study was supported also by grants from the Carlos III National Health Institute, National network ARADYALRD16/0006/0024, FIS PI15/00726 and FEDER funds. 


\section{Conflicts of Interest}

The authors declare that they have no conflicts of interest.

\section{References}

1. Doña I, Barrionuevo E, Blanca-Lopez N, Torres MJ, Fernandez TD, Mayorga C, Canto G, Blanca M. Trends in hypersensitivity drug reactions: more drugs, more response patterns, more heterogeneity. J Investig Allergol Clin Immunol. 2014;24(3):143-53.

2. Messaad D, Sahla H, Benahmed S, Godard P, Bousquet J, Demoly P. Drug provocation tests in patients with a history suggesting an immediate drug hypersensitivity reaction. Ann Intern Med. 2004;140(12):1001-6.

3. Jares EJ, Sanchez-Borges M, Cardona-Villa R, Ensina LF, AriasCruzA, Gomez M, Barayazarra S, Bernstein JA, Serrano CD, Cuello MN, Morfin-Maciel BM, De Falco A, Cherrez-Ojeda. Multinational experience with hypersensitivity drug reactions in Latin America. Ann Allergy Asthma Immunol. 2014;113(3):282-9.

4. Faria E, Rodrigues-Cernadas J, Gaspar A, Botelho C, Castro E, Lopes A, Gomes E, Malheiro D, Cadinha S, Campina-Costa S, Neto M, Sousa N, Rodrigues-Alves R, Romeira A, Caiado J, Morais-Almeida M. Drug-induced anaphylaxis survey in Portuguese Allergy Departments. J Investig Allergol Clin Immunol. 2014;24(1):40-8.

5. Aun MV, Blanca M, Garro LS, Ribeiro MR, Kalil J, Motta AA, Castells M, Giavina-Bianchi P. Nonsteroidal anti-inflammatory drugs are major causes of drug-induced anaphylaxis. J Allergy Clin Immunol Pract. 2014;2(4):414-20.

6. Antunez C, Martin E, Cornejo-Garcia JA, Blanca-Lopez N, R-Pena R, Mayorga C, Torres MJ, Blanca M. Immediate hypersensitivity reactions to penicillins and other betalactams. Curr Pharm Des. 2006;12(26):3327-33.

7. Kowalski ML, Asero R, Bavbek S, Blanca M, Blanca-Lopez N, Bochenek G, Brockow K, Campo P, Celik G, Cernadas J, Cortellini G, Gomes E, Niżankowska-Mogilnicka E, Romano A, Szczeklik A, Testi S, Torres MJ, Wöhrl S, Makowska J. Classification and practical approach to the diagnosis and management of hypersensitivity to nonsteroidal antiinflammatory drugs. Allergy. 2013;68(10):1219-32.

8. Doña I, Blanca-Lopez N, Cornejo-Garcia JA, Torres MJ, Laguna JJ, Fernandez J, Rosado A, Rondón C, Campo P, Agúndez JA, Blanca M, Canto $G$. Characteristics of subjects experiencing hypersensitivity to non-steroidal anti-inflammatory drugs: patterns of response. Clin Exp Allergy. 2011;41(1):86-95.

9. Canto MG, Andreu I, Fernandez J, Blanca M. Selective immediate hypersensitivity reactions to NSAIDs. Curr Opin Allergy Clin Immunol. 2009;9(4):293-7.

10. Demir S, Olgac M, Unal D, GelincikA, Colakoglu B, Buyukozturk S. Evaluation of hypersensitivity reactions to nonsteroidal anti-inflammatory drugs according to the latest classification. Allergy. 2015;70(11):1461-7.

11. Cornejo-Garcia JA, Blanca-Lopez N, Doña I, Andreu I, Agundez JA, Carballo M, Blanca M, Canto MG. Hypersensitivity reactions to non-steroidal anti-inflammatory drugs. Curr Drug Metab. 2009;10(9):971-80.

12. Zambonino MA, Torres MJ, Munoz C, Requena G, Mayorga C, Posadas T, Urda A, Blanca M, Corzo JL. Drug provocation tests in the diagnosis of hypersensitivity reactions to non-steroidal anti-inflammatory drugs in children. Pediatr Allergy Immunol. 2013;24(2):151-9.

13. Blanca-Lopez N, Cornejo-Garcia JA, Plaza-Seron MC, Doña I, Torres-Jaen MJ, Padilla-Espana L, Kidon M, Perkins JR, Blanca M. Hypersensitivity to Nonsteroidal Anti-inflammatory Drugs in Children and Adolescents: Cross-Intolerance Reactions. J Investig Allergol Clin Immunol. 2015;25(4):259-69.

14. Asero R, Bavbek S, Blanca M, Blanca-Lopez N, Cortellini G, Nizankowska-Mogilnicka E, Romano A, Szczeklik A, Testi S, Torres MJ, Wöhrl S, Makowska J. Clinical management of patients with a history of urticaria/angioedema induced by multiple NSAIDs: an expert panel review. Int Arch Allergy Immunol. 2013;160(2):126-33.

15. Papadopoulos NG, Agache I, Bavbek S, Bilo BM, Braido F, Cardona V, Custovic A, Demonchy J, Demoly P, Eigenmann P, Gayraud J, Grattan C, Heffler E, Hellings PW, Jutel M, Knol E, Lötvall J, Muraro A, Poulsen LK, Roberts G, SchmidGrendelmeier $P$, Skevaki C, Triggiani M, Vanree $R$, Werfel T, Flood B, Palkonen S, Savli R, Allegri P, Annesi-Maesano I, Annunziato F, Antolin-Amerigo D, Apfelbacher C, Blanca M, Bogacka E, Bonadonna P, Bonini M, Boyman O, Brockow K, Burney P, Buters J, Butiene I, Calderon M, Cardell LO, Caubet JC, Celenk S, Cichocka-Jarosz E, Cingi C, Couto M, Dejong N, Del Giacco S, Douladiris N, Fassio F, Fauquert JL, Fernandez J, Rivas MF, Ferrer M, Flohr C, Gardner J, Genuneit J, Gevaert P, Groblewska A, Hamelmann E, Hoffmann HJ, Hoffmann-Sommergruber K, Hovhannisyan L, Hox V, Jahnsen FL, Kalayci O, Kalpaklioglu AF, Kleine-Tebbe J, Konstantinou G, Kurowski M, Lau S, Lauener R, Lauerma A, Logan K, Magnan A, Makowska J, Makrinioti $H$, Mangina $P$, Manole $F$, Mari $A$, Mazon A, Mills C, Mingomataj E, Niggemann B, Nilsson G, Ollert M, O'Mahony L, O'Neil S, Pala G, Papi A, Passalacqua G, Perkin M, Pfaar O, Pitsios C, Quirce S, Raap U, Raulf-Heimsoth M, Rhyner C, Robson-Ansley P, Alves RR, Roje Z, Rondon C, Rudzeviciene 0 , Ruëff $F$, Rukhadze $M$, Rumi G, Sackesen $C$, Santos AF, Santucci A, Scharf C, Schmidt-Weber C, Schnyder B, Schwarze J, Senna G, Sergejeva S, Seys S, Siracusa A, Skypala I, Sokolowska M, Spertini F, Spiewak R, Sprikkelman A, Sturm G, Swoboda I, Terreehorst I, Toskala E, Traidl-Hoffmann C, Venter C, Vlieg-Boerstra B, Whitacker P, Worm M, Xepapadaki P, Akdis CA. Research needs in allergy: an EAACI position paper, in collaboration with EFA. Clin Transl Allergy. 2012;2(1):21.

16. Romano A, Pichler WJ, Blanca M. Highlights of the 4th Drug Hypersensitivity Meeting--Rome, April 22-25, 2010. Preface. J Allergy Clin Immunol. 2011;127(3 Suppl):S59.

17. Adkinson NF, Jr. Risk factors for drug allergy. J Allergy Clin Immunol. 1984;74(4 Pt 2):567-72.

18. Torres MJ, Blanca M. The complex clinical picture of beta-lactam hypersensitivity: penicillins, cephalosporins, monobactams, carbapenems, and clavams. Med Clin North Am. 2010;94(4):805-20, xii.

19. Harris RJ, Harris RL. Multiple antibiotic allergies. J Am Dent Assoc. 1978;97(6):994-5.

20. Sullivan T. Studies of the multiple drug allergy syndrome. J Allergy Clin Immunol. 1989;83:270.

21. Macy E. Multiple antibiotic allergy syndrome. Immunol Allergy Clin North Am. 2004;24(3):533-43, viii.

22. Chiriac AM, Demoly P. Multiple drug hypersensitivity syndrome. Curr Opin Allergy Clin Immunol. 2013;13(4):323-9. 
23. Antunez C, Fernandez T, Blanca-Lopez N, Torres MJ, Mayorga C, Canto G, Fernández J, Moya MC, Blanca M. IgE antibodies to betalactams: relationship between the triggering hapten and the specificity of the immune response. Allergy. 2006;61(8):940-6.

24. Daubner B, Groux-Keller M, Hausmann OV, Kawabata T, Naisbitt DJ, Park BK, Wendland T, Lerch M, Pichler WJ. Multiple drug hypersensitivity: normal Treg cell function but enhanced in vivo activation of drug-specific T cells. Allergy. 2012;67(1):58-66.

25. Pichler WJ, Daubner B, Kawabata T. Drug hypersensitivity: flare-up reactions, cross-reactivity and multiple drug hypersensitivity. J Dermatol. 2011;38(3):216-21.

26. Pérez-Sánchez N, Bogs G, Cornejo-García JA, Andreu I, Doña I, Blanca-López N. Multiple NSAID hypersensitivity without hypersensitivity to aspirin. J Allergy Clin Immunol Pract 2016; doi: 10.1016/j.jaip.2015.11.017. [Epub ahead of print].

27. Gomez E, Blanca-Lopez N, Torres MJ, Requena G, Rondon C, Canto G, Blanca M, Mayorga C. Immunoglobulin E-mediated immediate allergic reactions to dipyrone: value of basophil activation test in the identification of patients. Clin Exp Allergy. 2009;39(8):1217-24.

28. de Paramo BJ, Gancedo SQ, Cuevas M, Camo IP, Martin JA, Cosmes EL. Paracetamol (acetaminophen) hypersensitivity. Ann Allergy Asthma Immunol. 2000;85(6 Pt 1):508-11.

29. Harrer $A$, Lang $R$, Grims $R$, Braitsch $M$, Hawranek $T$, Aberer W, Vogel L, Schmid W, Ferreira F, Himly M. Diclofenac hypersensitivity: antibody responses to the parent drug and relevant metabolites. PLoS One. 2010;5(10):e13707.

30. Kowalski ML, Woessner K, Sanak M. Approaches to the diagnosis and management of patients with a history of nonsteroidal anti-inflammatory drug-related urticaria and angioedema. J Allergy Clin Immunol. 2015;136(2):245-51.

31. Gomes E, Cardoso MF, Praca F, Gomes L, Marino E, Demoly P. Self-reported drug allergy in a general adult Portuguese population. Clin Exp Allergy. 2004;34(10):1597-601.

32. Blanca-Lopez N, M JT, Doña I, Campo P, Rondon C, Seoane Reula ME, Salas M, Canto G, Blanca M. Value of the clinical history in the diagnosis of urticaria/angioedema induced by NSAIDs with cross-intolerance. Clin Exp Allergy. 2013;43(1):85-91.
33. Takahashi R, Kano Y, Yamazaki Y, Kimishima M, Mizukawa $Y$, Shiohara T. Defective regulatory $T$ cells in patients with severe drug eruptions: timing of the dysfunction is associated with the pathological phenotype and outcome. J Immunol. 2009; 182(12):8071-9.

34. Andreu I, Mayorga C, Miranda MA. Generation of reactive intermediates in photoallergic dermatitis. Curr Opin Allergy Clin Immunol. 2010;10(4):303-8.

35. Kowalski ML, Bienkiewicz B, Woszczek G, Iwaszkiewicz J, Poniatowska M. Diagnosis of pyrazolone drug sensitivity: clinical history versus skin testing and in vitro testing. Allergy Asthma Proc. 1999;20(6):347-52.

36. Himly $M$, Jahn-Schmid B, Pittertschatscher $K$, Bohle $B$, Grubmayr K, Ferreira F, Ebner H, Ebner C. IgE-mediated immediate-type hypersensitivity to the pyrazolone drug propyphenazone. J Allergy Clin Immunol. 2003;111(4):882-8.

37. Blanca M, Perez E, Garcia JJ, Miranda A, Terrados S, Vega JM, Suau R. Angioedema and IgE antibodies to aspirin: a case report. Ann Allergy. 1989;62(4):295-8.

38. Gala G, Blanco R, Quirce S, Perez-Camo I, Alvarez-Fernandez JA, Diez-Gomez ML. Diclofenac-induced urticaria with aspirin tolerance. Allergy. 1998;53(6):623-4.

39. del Pozo MD, Lobera T, Blasco A. Selective hypersensitivity to diclofenac. Allergy. 2000;55(4):412-3.

Manuscript received February 2, 2016; accepted for
publication May 19, 2016.

- Natalia Blanca-López

Servicio de Alergia

Hospital Infanta Leonor

Avenida Gran Vía del Este, 80

28031 Madrid, Spain

E-mail: natalia.blanca@gmail.com 